\title{
Approaches to the Organization of the Energy Efficient Activity at the Regional Level in the Context of Limited Budget Resources during the Transformation of Energy Market Paradigm
}

\author{
Ihor VAKULENKO, Iuliia MYROSHNYCHENKO* \\ Sumy State University, 2 Rymskogo-Korsakova St., 40007, Sumy city, Ukraine
}

\begin{abstract}
The research is devoted to the problem of the assessment of the integrated projects investment efficiency, energy saving and energy efficiency measures for social and municipal buildings within the course aimed at the reduction of the natural gas consumption and its replacement by alternative fuel types, that is important for a number of European countries, and Ukraine in particular. The objectives of the research are as follows: comparative assessment of the quality of integrated and element-by-element approaches to energy saving encompassing investment, environmental, social and organizational aspects; the formulation of practical recommendations to improve the efficiency of development and implementation of integrated programs in the field of energy saving and energy efficiency. It is proposed to use the methodology of system analysis with the elements of deduction that is practical and that allows to set key factors that influence the processes of energy replacement and energy efficiency increase, as well as factors that constrain them.
\end{abstract}

Keywords - Alternative fuel; energy efficiency of social objects; energy saving; financing of the energy efficiency projects

\section{INTRODUCTION}

This article aims to determine the expedience of the use of integrated programs on energy saving and energy efficiency at the regional level by local authorities. The existence of this problem in Ukraine is explained by the imbalance between funding of the measures on energy saving and energy efficiency of social and municipal buildings and the actual needs that these buildings have. The problem of the lack of money is typical for Ukraine for decades, so we have to acknowledge the cumulative negative effect of chronic underfunding in the sectors that have strategic importance for the functioning and development of the country. In recent years, the political and economic situation in Ukraine has especially deepened the problem of energy security of the country that is closely connected with the issues of energy independence and energy efficiency. The rise in price and the shortage of energy resources affected all sectors of the national economy. But the buildings of social importance (schools, kindergartens, medical institutions) which, as a rule, rest on the budget and management of state and local authorities and governments, and communal buildings are the most vulnerable to the negative effects on the energy market. The priority of the implementation of the projects on energy saving and energy efficiency at the aforementioned buildings have been declared by the highest bodies of state authority is the response to current trends on the energy market. However, the mechanisms of

\footnotetext{
* Corresponding author.

E-mail address: myroshnychenko@management.sumdu.edu.ua
} 
state policy implementation in this direction may differ. It could be the information and organizational support of the development and implementation of energy saving projects and the subsidies for local authorities and viewing of fiscal policy with the purpose to increase of the tax revenues shares that remain at the disposal of the local authority with their further investment in the projects on energy efficiency increasing. In any case, national policy should take into account the actual conditions of investment in energy efficiency. This will allow to reduce the number of failed projects and government initiatives. This issue is investigated in detail by Allcott and Greenstone [1].

The currently valid mechanism of the implementation of energy policy at the regional level is a scheme of co-funding of the projects by state and local authorities. Through the depressiveness of the economic situation in most regions, local authorities have no sufficient financial resources for independent implementation of energy efficiency measures at the regional level, as well as for participation in the programs of co-funding on equal with the government principles. Therefore, government funding is very important. Often, the share of local finance for the implementation of these projects is about $10 \%$. In order to attract state funds, local authorities have to first prepare a program that justifies the real need for investments aimed at increasing energy efficiency. In this research, we will consider the approaches for the development of a program in terms of its further implementation. There appears a problem of maximizing the economic, social and environmental effects of investment activity in this sector by taking into account the potential underfunding (amount of actual funding may be less than $30 \%$ of the real needs).

Regional policy on energy efficiency depends on several factors. Firstly, it must be carried out within the framework of national policy. Ukrainian national policy is based on the development of the strategy of power industry development [2] and the regional strategies are derived from this main strategy. Specification of the regional strategic tasks is carried out through the programs on the increase of energy efficiency in different sectors of economy. The development of these programs can be based on different approaches. The model of planning the energy system from the bottom up that promotes the development of alternative energy seems to be the prospective one. This model is described by Cormio et al. [3]. Also the prospective approach that is based on the SWOT analysis and can be used in the regions of Ukraine was studied in [4] by Terrados et al. In the context of this issue it is reasonable to pay attention to the suggestions of above mentioned Terrados et al. and also Pérez-Higueras that are given in [5]. It is also important evaluate the effectiveness of energy saving in the implementation of relevant programs, using the approach proposed by Asere and Blumberga in research [6] or using the approach proposed by scientists in research Zvingule et al. [7]. The highlighted issues above deal with the strategic management of the territory. However, the implementation of strategic objectives is directly connected with organizational aspects. In this research, we will focus on these aspects, namely the effective ways of investing in energy efficiency projects in the social sphere. The research is conducted from the standpoint of the managerial efficiency of local authorities.

\section{RESEARCH TASK}

According to the purpose set by us, the structure of the research will include the following stages or elements: 1 . the description of both considered approaches - integrated programs and element by element approach; 2. comparative characteristics of these approaches; 3. brief analysis of the approaches with the determining positive and negative aspects of each of them; 4 . 
justification of the rationale use of integrated programs on energy saving and energy efficiency at the regional level by local authorities under conditions of limited investment possibilities.

The last item of the research requires special attention because of significant amount of effects of different nature that should be studied in detail. Among all the effects, we have identified the followings: investment and economics, environmental, social, organizational, scientific and applied.

\section{Methodology}

According to the above mentioned algorithm of action, first of all it is necessary to describe the approaches that are studied to investigate their essence.

The approach, called by us as element-by-element, in fact represents itself the carrying out of an energy audit with further development of necessary set of documents for the development and implementation of the investment project for a particular building. Such approach to the energy saving (energy efficiency) is characterized by the implementation of several stages.

1. Pre-agreement (project identification): meeting of the Developer and Customer; preliminary acquaintance with the subject of energy audit; getting the preliminary information, its analysis and the development of the plan of energy audit.

2. Organizational and preparatory (documentation): coordination with Customer the plan of conducting an energy audit, signing of agreement, establishment of energy audit training group.

3. Performance (information gathering): acquaintance of Developer with the information and measurements to be conducted at the building of energy audit.

4. Determination of energy saving reserves and potential of improvements (simplified audit or detailed audit with guarantees): performance of analysis of the results obtained, assessment of the potential of energy savings and basic technical and economic indexes of efficiency of the use of fuel and energy resources, analysis of the efficiency of the functioning energy management system.

5. Recommendations (transfer of the energy audit conclusions): development and technical and economic assessment of the effectiveness of priority list of energy saving measures. The Developer prepares and transfers the report and energy audit conclusion to the Customer. Giving the presentation of the main results of energy audit to the Customer.

6. Business plan: preparing business plan taking into account the following: potential of energy efficiency increasing of the building of energy audit; Customer's plans on the renovation; profitability of energy efficiency measures; achieving social and environmental effect.

7. Business plan implementation: implementation of business project on increasing the building's energy efficiency.

8. Maintenance: organization by Customer of a set of measures carried out daily, weekly and/or monthly to maintain the calculated level of energy saving and proper condition of the functioning of energy audit site, its technical installations.

The economic justification of solutions that are provided by the project is a key aspect of the successful implementation of the investment project on energy saving. To assess the reasonability and effectiveness of the project implementation, it is necessary to conduct the research in accordance with the following algorithm:

I stage: development of the technical part of the audit, i.e. propositions on the implementation of engineering and technical measures. 
- assessment of the technical capability of the new construction, reconstruction, major repairs and technical re-equipment of the site for the energy saving project;

- analysis of engineering surveys, the schemes of the general plan and the summary plan of engineering networks;

- comparison of the main technological, construction and architectural and planning data and the solution on the implementation of energy saving measures;

- justification of conclusions with choosing the selected option of the proposed solutions and the audit proposals;

- determination of the stages of project development;

- determination of the number of jobs, including recently created ones.

II stage: technical and economic assessment of the effectiveness of investments in energy saving project.

- assessment of the estimated cost of construction, including the construction activities, equipment, commissioning works, other costs, depreciation;

- calculation of the costs on allocation of land for construction and installation work (if needed);

- calculation of the amount of investments for project development and the possibility of their inclusion (usually the energy saving measures require one-time investment);

- determination of the structure of investment capital and the cost of each year of the project life cycle;

- assessment of market for sale of goods, planned output, main customers, competitors;

- assessment of the economic, social and environmental effects as a result of the project implementation.

- assessment of costs on the protection of the natural environment, rehabilitation and countervailing measures;

- comparison of the project effectiveness with the alternative projects (investments in "portfolio investment " or investments in other industries);

- determination of the advantages and disadvantages of the project in comparison with similar ones in domestic and foreign practice [8].

Thus, this approach to the problem solving on energy efficiency at the regional level from the perspective of local government means the need for a detailed assessment of all buildings that should be reconstructed, upgraded or repaired. There is in need to improve their characteristics in terms of efficient use of fuel and energy resources. Accordingly, this approach has a high cost and long term examination of all sites.

The approach based on the development of integrated program on energy saving can be used as opposed to the element by element approach that is described above. The process of such program development also consists of a list of necessary stages. We offer the algorithm of development of integrated program as it was used while developing "Regional program of modernization of heating systems of Sumy region for the period 2014-2018". However, we made adjustments to eliminate the drawbacks of the mechanism of the further implementation of program that were found in practice.

Thus, the algorithm of the development of the integrated program on energy saving (energy efficiency) for certain region can be grouped into three blocks (technical, economic and organizational) (Table 1).

Let us consider every item in more detail. Assessment of the scale of the project is the first stage of the program development. Usually, the purpose and tasks of the program are determined first, but in our case the purpose was determined beforehand and the tasks were outlined. That is why we can omit the process of purpose and task setting. And, correspondingly, the starting point for us is the very start work of program development with defined requirements and key 
parameters. At the stage of assessment of the scale of the program the developers (of program) have to determine the number of objects to be included. We consider the determining of object number through the adjustment of the list-oriented objects number to be the most all-embracing variant. This variant consists in removal from the general list of the buildings of social function and those which are communal property, which a number of reasons should not be included in the program. For example, it is unreasonable to include in the program the buildings which already meet the energy efficiency requirements. At this stage it is necessary to collect the technical data on the buildings to be included in the program.

\section{TABLE 1. Algorithm OF THE INTEGRATED PROGRAM DEVELOPMENT}

\begin{tabular}{ll}
\hline & Assessment of the scale of the project \\
Technical & Typology of the objects \\
block & Conceptualization \\
& Element by element projecting \\
& Adjustment \\
\hline $\begin{array}{l}\text { Economic } \\
\text { block }\end{array}$ & Object by object assessment of the effectiveness \\
\hline $\begin{array}{l}\text { Organizational } \\
\text { block }\end{array}$ & Roadmap development \\
\hline
\end{tabular}

The typology of the buildings is the next stage of program development. It consists in the building classification according to their intended use, size, location (urban and rural sites), date of construction, date of latest upgrading, etc. This stage is very important from the standpoint of preparation for the next stage, called the conceptualization.

Conceptualization provides the preparation of typical technical and technological solutions for different building groups that were selected at the previous stage.

The preparation of typical solutions allows to simplify the development of the program and the purchase processes that accompany it. Moreover, this approach reduces the cost of energy audit conducted at the buildings included in the program that will be discussed later. A significant disadvantage of such approach is the lack of individual approach to the energy audit of a building. However, the qualitatively performed typology allows to largely eliminate this disadvantage. Let's illustrate it by an example. "Education institutions in rural areas built between 1970-1990 without conducting the capital measures on energy efficiency" can be one of the selected groups that will receive the typical technical and technological solution. As in Soviet times, the building of schools and their connection to the heating was standard, it is obvious that the majority of the buildings of this group will have a similar system of engineering buildings and communications. And, correspondingly, the technical and technological solutions for one of the sites of this group can be applied to others after some adjustments. The reequipment of boiler, that serves the house, for the alternative fuel, the construction of the warehouse for alternative fuel storage, changing the temperature regime of heating equipment work, insulating the facades, etc., are examples of such technical and technological solutions. The development of a project of energy efficiency measures of a particular building is based on the work with its technical documentation received at the first stage of program development. The stage at which this work is carried out is called element by element projecting. However, the project developed at this stage for a particular building cannot be approved and submitted to be used in future without clarifying the details and making necessary changes. The clarifying of details is conducted through the field research of the building by specialists who develop the 
project and through consultations with persons responsible for the building at the local level. This allows to avoid mistakes during the project and to take into account the peculiarities of each building. The process of clarifying is conducted at the stage of adjustment.

It should be noted that the process of program development includes three conditional blocks: technical, economic and organizational. The technical block of program development includes all the above described stages. Work within the technical and economic blocks can be conducted in parallel, but the organizational block should be developed only after finishing work on the previous ones.

The next stage of work on the program is building by building efficiency assessment. At this stage, the work on the development of the technical and technological justification of the proposed technical and technological measures and development of the project (if needed) is carried out:

The assessment of economic efficiency of energy saving measures is based on the calculation of the following indicators [8]-[10]:

1) cash flow.

2) profit from the energy saving measures implementation/development $\left(P_{t}\right)$ :

$$
P_{t}=I_{t}-C_{t},
$$

where

$P_{t} \quad$ profit received from the implementation of the energy saving measures during $t$-year of measures implementation;

$I_{t} \quad$ savings and additional income received from the implementation of the energy saving measures during $t$-year of measures implementation;

$C_{t} \quad$ costs on the energy saving measures implementation during $t$-year of measures implementation.

3) net present value (NPV):

$$
N P V=\sum_{k=1}^{n} \frac{C F_{k}}{(1+r)^{k}}-\sum_{k=1}^{n} \frac{I_{k}}{(1+r)^{k}},
$$

where

$n \quad$ project implementation period;

$C F_{k} \quad$ net cash flow during $k$-year;

$r \quad$ discount rate;

$I_{k} \quad$ investment costs during $k$-year;

$k \quad$ ordinal number of year from the beginning of the project.

4) internal rate of return (IRR):

$$
I R R=r_{a}+\frac{N P V_{a}}{N P V_{a}-N P V_{b}}\left(r_{b}-r_{a}\right),
$$

where

$r_{a} \quad$ lower discount rate chosen;

$r_{b} \quad$ higher discount rate chosen;

$N_{a} \quad N P V$ at $r_{a}$;

$N_{b} \quad N P V$ at $r_{b}$. 
5) discounted payback period $(D P P)$ :

$$
D P P=A+\frac{B}{C}
$$

where

A last period with a negative discounted cumulative cash flow;

$B \quad$ absolute value of discounted cumulative cash flow at the end of the period $A$;

$C$ discounted cash flow during the period after $A$.

6) profitability index $(P I)$ :

$$
P I=\sum_{k=1}^{n} \frac{C F_{k}}{(1+r)^{k}} / \sum_{k=1}^{n} \frac{I_{k}}{(1+r)^{k}}
$$

The above mentioned indexes are the basic ones for calculating the economic efficiency of the project, but, in our opinion, it is reasonable to introduce an additional index of threshold value of reinvesting of profit into the reconstruction. This index reflects the threshold of the economically reasonable investment in the object.

The addition of the indicator $\left(P_{r}\right)$ is caused by the need to verify the information on the volume of necessary investment resources in order to prevent their overestimation. In this methodology, this indicator is used as an element of anti-corruption and it makes it impossible to attract the funds in amounts exceeding the economically expedient ones.

The threshold value of reinvesting of profit into the reconstruction (investment from other sources - borrowed funds) is calculated by the formula:

$$
\begin{gathered}
P_{r}=\frac{\left(V_{1}-M_{1}-a F_{0}\right)-\left(w_{1} / w_{0}\right)\left(V_{0}-M_{0}-a F_{0}\right)}{a+1 / e}, \\
e=\frac{(1+i)^{T}-1}{i(1+i)^{T-1}},
\end{gathered}
$$

where

$V_{0} \quad$ income before investment project implementation;

$V_{1} \quad$ income after investment project implementation;

$M_{0} \quad$ material costs without depreciation before investment project implementation;

$M_{1} \quad$ material costs without depreciation after investment project implementation;

$F_{0} \quad$ amount of depreciation;

a depreciation charge;

$i \quad$ discount rate;

$T \quad$ duration of project life cycle;

$w_{0}, w_{1}$ the number of employees before and after the implementation of investment project, respectively [11].

It is expedient to use a value of alternative losses while analyzing the project economic efficiency. The use of the indicator $\left(V_{a l t}\right)$ is reasonable in cases where the economic efficiency of the project is not obvious. That is the value of $N P V$ is close to zero or is negative. For example, the cost of the replacement of underground utilities is, in most cases, higher than the value of its economic effect. However, the losses on the liquidation of the disruption of these utilities are 
higher than the value of their scheduled replacement. Therefore, the understanding of the value of the alternative losses is important for the decision making on this project investment.

The alternative losses are proposed to be calculated by the formula:

$$
V_{a l t}=\sum_{i=1}^{n} \frac{V_{i}}{(1+r)^{i}},
$$

where

$V_{\text {alt }} \quad$ total sum of alternative losses;

$V_{i} \quad$ amount of alternative losses by cost item $i$;

$n \quad$ number of cost items of loss;

$r \quad$ discount rate.

Therewith, at this stage, indexes of environmental and social impact of the project implementation are given.

The next stage of the integrated program development is consolidation. Actually, it means that all materials on different buildings included in the program, are merged into a single report. The report contains technical and economic data on project as a whole, as well as justification of the possibility and reasonability of program implementation. Materials on the individual buildings are formed in the appendixes. This is the final stage in the conditionally identified economic block.

At this stage the development of the program can be considered completed. However, from a practical point of view, namely the prospects for effective use of the developed program to increase the energy efficiency at the regional level it is expedient to work more at the organizational block that can be documented as an appendix to the program, or its separate section. This block consists of two stages, namely the development of "roadmap" and scientific and practical recommendations. The "roadmap" is developed as an instruction for local authorities on the priority and order of investment projects development at the buildings included in the program. It means that there is given the justification of the most effective use of funds on projects implementation to obtain maximum economic effect with taking into account social component. Also, the availability of the "roadmap" can simplify duties execution for government officials and reduce the corruption component.

The final stage of program development is to develop scientific and practical recommendations. At this stage it is expected to provide a brief report that contains scientifically reasoned recommendations on resource provision of the program and potential trends of the development of related areas that can be caused by program implementation and related processes with appropriate recommended measures. It allows to avoid potentially undesirable effects. For example, if the program provides significant increase of the alternative fuels consumption (wood, peat, pellets, briquettes, coal) due to the re-equipment of boilers to alternative fuels. It is necessary to take into account these changes while planning and management of the corresponding industry.

\section{Results}

Thus, now we have considered two approaches to the organization of the process of the energy efficiency management at the level of separate region. Each approach has its own peculiarities, advantages and disadvantages. The use of each of them is justified in some specified conditions. However, it is expedient to conduct the above mentioned systemization for better understanding of common features and differences of described approaches. For clarity, the comparative characteristic of both approaches is given in Table 2: 
TABLE 2. COMPARISON OF ELEMENT BY ELEMENT APPROACH AND INTEGRATED PROGRAM APPROACH

\begin{tabular}{lcc}
\hline \multicolumn{1}{c}{ Characteristics } & $\begin{array}{c}\text { Element by } \\
\text { element approach }\end{array}$ & $\begin{array}{c}\text { Integrated } \\
\text { program approach }\end{array}$ \\
\hline Individual approach & YES & NO \\
Necessity for conducting a detailed energy audit & YES & NO \\
Need for agreements between the developer and the & YES & NO \\
buildings to be examined & YES & YES \\
Providing the technical and engineering recommendations & YES & NO \\
Development of business plan for the project & YES & YES \\
Development of investment project (if needed) & YES & NO \\
High cost of project development per one building & NO & YES \\
Systematization of objects data & NO & YES \\
Availability of «Roadmap» & NO & YES \\
Availability of (compulsory) complex report & YES & YES \\
Calculation of economic, environmental and social effects & NO & YES \\
Fulfillment of work mainly by one organization & \\
\hline
\end{tabular}

Thus, the above mentioned comparative characteristics of two approaches to the implementation of the policy on energy efficiency and energy saving at the regional level allow to clarify the choice of either variant, depending on the circumstances. Element by element approach is a typical scheme of the energy efficiency project development that is used in the world for a long time and is the application of business approach. At the same time, as opposed to the approach mentioned above the approach of using integrated programs has the characteristics peculiar to bureaucratic mechanism of problems solving that is based on centralization and unification. This is the first look at these approaches. But, the situation is somewhat more complicated if to the process of these approaches assessment the actual circumstances and conditions of the implementation of the state policy in situation of limited budgetary resources are added. Let's analyze separately each approach on the base of the information given above and answer the question of which one should be used under conditions of Ukrainian budget realities. For clarity, the advantages and disadvantages of each approach are shown in Fig. 1 and Fig. 2, respectively. 


\begin{tabular}{|c|c|}
\hline STRENGTH & WEAKNESS \\
\hline $\begin{array}{l}\text { - individual approach; } \\
\text { - significant amount of details on technical } \\
\text { solutions; } \\
\text { - in-depth economic (social, environmental } \\
\text { and economic) calculation of the efficiency; } \\
\text { - legal guarantees of the work quality; } \\
\text { - direct connection between the customer and } \\
\text { developer. }\end{array}$ & $\begin{array}{l}\text { - lack of the systemization of data (data } \\
\text { differ); } \\
\text { - absence of roadmap; } \\
\text { - absence of compulsory final report; } \\
\text { - high cost. }\end{array}$ \\
\hline OPPORTUNITY & THREAT \\
\hline $\begin{array}{l}\text { - providing the high quality of the projects on } \\
\text { energy saving; } \\
\text { - promote competition in the market of } \\
\text { energy audit; } \\
\text { - higher probability of private investors } \\
\text { attracting. }\end{array}$ & $\begin{array}{l}\text { - absence of a systematic control over the } \\
\text { process on energy efficiency increasing in } \\
\text { social sphere (including the implementation } \\
\text { of projects that have been developed first, } \\
\text { instead of the most important); } \\
\text { - a potentially small number of covered } \\
\text { objects under conditions of limited budget. }\end{array}$ \\
\hline
\end{tabular}

Fig. 1. SWOT-analyzes of element by element approach for developing energy saving project.

To summarize the advantages and disadvantages of each approach, it is possible to come to the conclusion on the expediency of use of each of them in particular conditions of state policy implementation. Element by element approach has a number of advantages that emphasize its quality component first. This approach is balanced, accurate, with an individual approach to each building that certainly gives it significant advantages. However, the cost of this approach is high, that is largely due to the significant cost on skilled labor that is involved in the process of energy audits, development of technical solutions and technical documentation preparation as well as in-depth economic analysis. The analysis contains the technical and economic justification and (if needed) provides the development of business plan for the upgraded object. Besides, this approach does not provide the systemization of information on the buildings to be reconstructed or upgraded with purpose to increase their energy efficiency that would be useful in the context of regional management. We highlight this aspect, by focusing on the Ukrainian realities of limited attracted resources of foreign investor as well as private domestic ones. Therefore, the systematization and centralization of data is useful tool to increase the efficiency of measures on energy efficiency and energy saving due to integrated system approach. Thus, element by element approach is good market tool that can be used by state and local authorities to implement energy policy, particularly in cases of probable attracting of extra-budgetary funding. 


\begin{tabular}{|c|c|}
\hline STRENGTH & WEAKNESS \\
\hline $\begin{array}{l}\text { - low cost of the project calculated per } \\
\text { building; } \\
\text { - systematization of data on buildings; } \\
\text { - availability of "roadmap"; } \\
\text { - final integrated report provision. }\end{array}$ & $\begin{array}{l}\text { - not taking into consideration the } \\
\text { peculiarities of particular objects; } \\
\text { - simplified energy audit; } \\
\text { - presence of mediator (represented by the } \\
\text { local authority) between the representatives } \\
\text { of the building and the performer } \\
\text { (developer of program); } \\
\text { - a long period of program development. }\end{array}$ \\
\hline OPPORTUNITY & THREAT \\
\hline $\begin{array}{l}\text { - maximum coverage of objects of social and } \\
\text { communal property; } \\
\text { - spending of saved money from the use of } \\
\text { this approach on additional projects; } \\
\text { - significant control over the process on } \\
\text { increasing of energy efficiency by local } \\
\text { authorities; } \\
\text { - preferred implementation of the most } \\
\text { effective and important projects. }\end{array}$ & $\begin{array}{l}\text { - risk of mistakes in the technical and } \\
\text { economic components of the project; } \\
\text { - absence of interest of private investor to the } \\
\text { data of integrated program that does not } \\
\text { assist in investments attracting. }\end{array}$ \\
\hline
\end{tabular}

Fig. 2. SWOT-analyzes of integrated program approach for developing energy saving project.

Another approach, which we consider here, is the development of integrated programs, that also has a number of advantages and disadvantages that allow it to be qualitatively different from the element by element approach. Main advantages of this approach are as follows: lower cost of development, integrated approach, systematically, the possibility of preparation of integrated reports for stakeholders (both state and local government and non-governmental organizations and private entities), as well as prospects of the further use of the information on this program to manage the related fields of activity that can lead to the improvement of the management of the territory. However, the list of disadvantages of this approach is not shorter. The main disadvantage consists in that fact that the simplification of the energy audit of particular buildings may lead to choosing less effective technical solutions for the building. It is expedient to highlight the following disadvantages too: long period of program development and incomplete set of necessary documents for the project development in case of attracting of private investor.

Considering the above mentioned, we tend to use the integrated programs on energy saving and energy efficiency of regions in conditions of limited budgetary resources and the difficulties in the involvement of extra-budgetary funding. Such situation is observed in Ukraine now, and the statistics given in Table 3 are the evidences of it. Basic statistical indicators of Ukrainian economy have been taken from the Financial portal of the Ministry of Finance [12].

In this situation, it is important to identify the determining factors for the implementation of the state policy in the field of energy saving and increasing of energy efficiency, and regional policy as derived from it. In our opinion, such factors are as follows: economic efficiency, the amount of necessary state funding, the number of upgraded or reconstructed buildings and time. Accordingly, the amount of state funding and time for projects development should be minimal, and the number of upgraded sites and economic efficiency should be at a maximum. This leads to a contradiction that must be resolved. 
TABLE 3. BASIC STATISTICAL INDICATORS OF UKRAINIAN ECONOMY

\begin{tabular}{lllll}
\hline Indicators & $\begin{array}{l}\text { Unit of } \\
\text { measurement }\end{array}$ & 2013 year & 2014 year & \% \\
\hline $\begin{array}{l}\text { GDP of Ukraine (at } \\
\text { current prices) }\end{array}$ & $\begin{array}{l}\text { million UAH } \\
\text { (million USD) }\end{array}$ & $\begin{array}{l}1454931 \\
(127815)\end{array}$ & $\begin{array}{l}1566728 \\
(111443)\end{array}$ & +7.7 \\
$\begin{array}{l}\text { GDP of Ukraine } \\
\text { (nominal, USD) }\end{array}$ & million USD & 182026 & 130908 & -28.1 \\
$\begin{array}{l}\text { State capital } \\
\text { investments }\end{array}$ & $\begin{array}{l}\text { million UAH } \\
\text { (million USD) }\end{array}$ & $\underline{247891.6}$ & $\underline{204061.7}$ & -17.7 \\
$\begin{array}{l}\text { Foreign direct } \\
\text { investment in Ukraine }\end{array}$ & million USD & 4499 & $(17931.6)$ & \\
\hline
\end{tabular}

Returning to the comparison of approaches (which we consider here), namely to a list of their advantages and disadvantages, and comparing them with the criteria by which the efficiency of implementation of national and regional policy in this sphere will be assessed, it can be concluded that it is preferable to use element by element approach. It allows to increase the probability of the maximum economic effect for a particular site, to reduce the time from the beginning of development to its implementation and also has the advantages in terms of private investment attracting. The only parameter that does not correspond to this approach is the amount of buildings covered that is explained by high cost of project development for particular object. However, this disadvantage can be neutralized if the stakeholder will pay these costs. Thus, theoretically this approach is optimal and appropriate. However, in practice it is not so. In fact, the above mentioned data of the economic condition of state and dynamics of the development of some industries in combination with the indicators of attracted investment resources, provide clear understanding of the real sources of funding for the industry, that can be the budgets of different levels (state, regional, local). It means that economic efficiency, with taking into account the social component that will be reflected in the number of objects that will be upgraded, is the real criterion of state policy assessment in the field of energy efficiency and energy saving in social and municipal sectors. Accordingly, the contradiction between the criteria, which we discussed above, will be eliminated by finding the optimal relations between the indicators of economic efficiency and number of covered objects. As a conclusion, the emphasis will be placed on the implementation of the minimum required set of technical and technological measures (solutions) at the maximum possible number of objects. Thus, the finding of mentioned optimum is a key task that should be solved in practice. The development of integrated regional programs is the priority variant of the approach to the implementation of state and regional policy in the studied field for such purposes. It is connected with their complexity and consistency as well as the possibility of the development of several variants of the technical solutions (with economic justification) for each object depending on the forecasted (or planned) amount of funding without significant increase of the cost of program development. One more argument for the choosing of integrated programs is the possibility (and practical necessity) of the development of "roadmap" for the program development. It allows the local authorities to make informed decisions on the procedure of funding implementation of objects covered by program to get maximum possible economic and social effect.

Further, it is expedient to consider the expected results of the development of the program or the effects. Previously, we identified the following effects: economic and investment, social, environmental, organizational and scientific and applied. Let us consider each of them. 
Economic and investment effects. The saving in program development in comparison with costs spent for the same amount of work while using element by element approach is the primary effect not by importance but by the time of occurrence. As an example of the comparison of the values for the development of integrated program and element by element approach, let us compare the cost of the corresponding amount of work by the example of "Regional program of modernization of heating systems of Sumy region for the period 20142018" and the performance of the same amount of work during an energy audit conducting. This program contains the results of examinations of condition of heating systems in biggest cities of region, the necessary analytics for problem areas identifying and the recommendations on the efficiency increasing of the functioning of the examined objects. Thus, the program covered municipal objects (facilities) of 11 district centers of the region and the regional center. By comparison, let us take the estimated cost of the audit conducted by the Association of energy auditors of Ukraine [13] using the methodology of pricing for energy audit of enterprises of district heating [14]. Comparative calculations by the example of Sumy region show that the cost of the development of "Regional program of modernization of heating systems of Sumy region for the period 2014-2018" is 4-4.5 time less than the corresponding amount of energy audit services provided by the energy audit companies. The calculations are based on the average cost of the energy audit conducting of the enterprises of the heat networks of cities calculated per one citizen (1.8-2 UAH/person (0.07-0.08 USD/person) (on the basis of the initial data on the cost of the energy audit according to the Association of Energy Auditors of Ukraine)) and on the comparison of the resulting amount with the cost of regional program development. The cost of the program makes UAH 300 thousand (USD 12.021 thousand), the cost of the same volume of services on energy audit is in the range of UAH 1.2-1.34 million (USD 0.048-0.054 million). Exchange rate of UKRAINE HRYVNAS (UAH) to US DOLLAR (USD) is taken for the further calculation as of 26.04.2015 and makes 24.9547 UAH = 1.00 USD.

To understand the amount of saving it is expedient to compare the cost of conducting an energy audit for a number of objects of social sphere and the development of integrated program for these objects.

Statistical data on the number of objects are shown in Table 4. Number of objects of social sphere of Sumy region have been taken from Department of Statistics in the Sumy region [15].

\section{TABLE 4. Number of OBJECTS OF SOCIAL SPHERE OF SUMY REGION}

\begin{tabular}{ll}
\hline Type of an institution & Number, pcs. \\
\hline Pre-school institutions & 513 \\
Schools & 540 \\
Trade schools & 33 \\
Higher educational institutions & 10 \\
(of different accreditation levels) & \\
Hospitals & 60 \\
Outpatient treatment facilities & 279 \\
\hline
\end{tabular}

Let us calculate the total cost of the energy audit of these institutions using the aggregated method and the average cost and energy audit of public institutions according to the data of the Association of Energy Auditors of Ukraine that makes UAH 10-14 thousand (USD 0.4-0.5 thousand) per 1 object.

Thus, the total cost will be calculated by formula: 


$$
C=V \sum_{i=1}^{n} N
$$

where

$C \quad$ total cost of energy audit conducting;

$V \quad$ average cost of energy audit conducting per 1 object of social sphere;

$N \quad$ number of institutions of particular type;

$i \quad$ type of institution;

$n \quad$ number of institution types.

Calculate value of total cost of energy audit will make:

$C=12 \cdot 1435=17220$ (thnd. UAH)

Thus, UAH 17.220 million (USD 0.69 million) of budget funds will be spent while using element by element approach only for the examination and preparation of project documentation for the buildings of social sphere.

To develop the integrated program with the initial parameters given in Table 5 it is necessary to spend approximately UAH 3.45 million (USD 0.14 million) (this calculation based on Model Regulations for planning, accounting and calculation of the cost of research and development work [16]-[17].

Thus, the difference in the cost of conducting the energy audit and of preparing the necessary documentation for the two above mentioned approaches will make 13.77 million UAH (17.223.45). As these funds have the target direction, they must be used directly for the implementation of energy efficiency projects for public institution modernization. It means that the redistribution of the amount of savings (13.77 million UAH) takes place within budgetary subventions. Now these funds are available not for the preparation of project documentation, but, for the implementation of projects (the purchase of equipment, salary for the staff involved in the modernization, carrying out the construction and installation and commissioning works). Thus, it is possible to achieve the increasing number of the upgraded buildings within the allocated funds. Thus, at the stage of the decision making on the integrated program use instead of element by element approach it is possible to improve the expected results of the implementation of national and regional policy in the field of energy saving and energy efficiency. It means that the number of upgraded buildings will be bigger while using an integrated program in comparison with use of element by element approach. This is a significant result for the local authorities.

TABLE 5. INTEGRATED PROGRAM PARAMETERS

\begin{tabular}{lcc}
\hline Parameter & Unit of measurement & Value \\
\hline Number of facilities & pcs. & 1435 \\
$\begin{array}{l}\text { Average time of work } \\
\text { on the object, incl.: }\end{array}$ & days & 6 \\
Analysis of situation & & 1 \\
Measurement & & 1 \\
Work with data & & 3 \\
Report preparation & months & $16-18$ \\
Duration of program & & \\
\hline
\end{tabular}


The number of such projects can be calculated by dividing the amount of saving by the cost of typical project on the upgrading of heating system of state-financed building. As an example, let us consider the project on the upgrading of the boiler room of one of the rural schools of Sumy region (Ukraine) that was developed in 2014.

General information on the measures provided by the project is as follow: 1. installation of two solid fuel boilers in the existing boiler room (calculated thermal power of the object after upgrading is $754 \mathrm{~kW}$ ); 2 . installation of network and circulation pumps; 3 . arrangement of the access road to the boiler room and the existing underground fire tanks; 4. water pipeline installation of polyethylene pipes from the existing wells; 5 . installation of cable entry from the existing gas module boiler to the electrical box of the boiler that is projected at solid fuel fired boilers; 6 . installation of closed volume compensator and equipment of automatic compensation of system with water softening equipment. The development of project requires the investments in the amount of UAH 996.268 thousand (USD 40 thousand) [8]. Taking into account the growth in prices of equipment and materials, required for the project, the real cost based on market prices as of April 2015 makes about UAH 1.4-1.5 million (USD 0.05-0.06 million). Focusing on the data mentioned above, it can be concluded that the total savings in the development of integrated program will allow to develop an additional 9 typical projects. Thus, UAH 13.77 million (USD 0.55 million), which will be additionally involved for particular projects implementation, make the amount of investment effect.

As further upgraded projects will reduce natural gas consumption.

But the economic effects of the integrated program development are not limited by saving through not using the element by element approach. It is necessary to distinguish among the additional results the effect of stimulating of the development of alternative energy at the regional level. This is due to the growing share of alternative energy in the energy balance of the region. This effect is caused by the philosophy of the program, namely the maximum possible replacement of traditional energy resources (natural gas) by alternative renewable energy sources. This philosophy corresponds to the trends and directions of state policy in the field of energy efficiency and energy saving. In addition to the above mentioned, it should be noted that during the development of the program the regional natural and economic characteristics that are taken into account and this contributes to the rapid development of alternative energy resources in the region, and then acts as a catalyst for the market, at the same time the attracting of private investments in the region economy and creating of new jobs. But, at present moment the calculation of additional effects is impossible due to a number of factors, including the absence of developed program with concrete indexes, as well as to the amount of possible funding of such program, etc.

It is necessary to distinguish among the other results of the development and implementation of integrated program the social and environmental effects. It is quite difficult to find the value terms of social effect due to the vagueness of the concept and the complicated calculations. In addition, the components of the social effect are not generic, that is, for a variety of projects they can be different, that causes additional difficulties in the calculation, as makes it difficult or impossible to apply one approach. However, it is difficult to assess the value of social effects of the projects implementation, even if they are of one type. It is expedient to divide all social effects of two groups: 1) quantitative; 2) qualitative. The first group includes such effects, the value of which can be calculated by use of simple mathematical procedures that is connected with their quantitative nature, for example, the effect of the creating of new jobs. The second group includes those effects that cannot be calculated accurately by elementary mathematical procedures, as these effects are expressed in qualitative, rather than quantitative indexes, such as improving quality of services on heat supply in the result of the reconstruction of school or preschool institutions, because the value terms of this effect is connected, for example, with the cost 
reduction on health and medical care as a result of sickness rate reduction (caused by hypothermia, etc.) among children of preschool and school age who study in these institutions [8].

In our case, the conditions of learning environment of more than 140 thousand children attending kindergartens, schoolchildren of secondary schools and trade schools, as well as about 10 thousand people who are on the inpatient treatment in health care institutions can be improved under condition of full coverage of objects of social sphere in the program development and if this program will be completely implemented.

The calculation of environmental effect of integrated program implementation (just as in previous cases) is possible only after the development of the program with concrete indexes. However, there are certain points to be mentioned.

Environmental effects of the implementation of an integrated program should be divided into two types.

The first type should include the change of the amount of harmful substances emissions into the atmosphere. The calculation is based on data on the amount of used fuel and its type before and after the modernization.

In general, the program can be used as an information base for the calculation of a significant number of environmental efficiency indicators. It is reasonable to determine the list of indicators and methodology of calculation at the national level. In this aspect, attention should be paid to the research [18] of Olsthoorna et al.

The second type should include the effects caused by the specificity of national policy in the field of energy efficiency and energy saving. It concerns the maximum possible replacement of non-renewable energy resources (natural gas) by biological renewable ones. It means that in every region there will be changed the structure of the energy balance in the direction of increasing the mining (production) and consumption of alternative energy resources that are available in the area. The impact of this process on the environment should also be taken into account. The large scale of this phenomenon can cause the increase of load on the ecosystem by the intensive logging or peat extraction or changes in the agricultural sector, etc. Mitigation of the possible negative effects of the increased load on the ecosystem can be systematically and comprehensively developed on the basis of data received while developing the program and statistics. In practice it is the use of actions on environment pollution along with the methods of its preventive protection. Accordingly the calculation of environmental effect of program implementation will include not only the effects of changes of environment but also the sum of prevented damage [19]. It is possible to get the maximum value of prevented damage by combining the data of integrated program and perspective plans of the development of related sectors of the economy and by taking into account the trends in the development of the regional market of energy resources.

Thus, the choice of integrated program as a mechanism of the implementation of energy efficiency policy in comparison with element by element approach provides an additional advantage in terms of environment protection activity.

Additionally, it is necessary to emphasis the effect of the development of integrated program, which is to improve the quality of management of the territory by the availability of the "roadmap" that provides local authorities with justified information on which projects should be developed firstly and what effect is expected. This variant is very useful in conditions of limited budgetary resources. The "roadmap" should provide the clear criteria system for determining the priority of project implementation. The integrated program contains all necessary data. Such criteria may be as follows: the potential to reduce energy consumption, the ratio between economic result and the costs, etc. 
The advantage of the integrated programs is also the scientific and applied effect that consists in the possibility of use of analytical and summarized data in management, regulation and promotion of related fields, such as forestry and agriculture that can lead to an improvement of indexes of the functioning of these sectors of economy.

\section{Conclusion}

The implementation of state and regional policy on energy saving and energy efficiency can be implemented in various ways. We have considered two approaches: element by element approach and the approach based on the development of integrated program on energy saving and energy efficiency. The complex of institutions of public sector at the level of administrative units, namely region, is the object of each program. Each approach has its advantages as well as disadvantages. However, during the assessment of the efficiency of the use of approaches under conditions of limited budgetary funding and an extremely low probability of private investment attracting in this sector, the approach that is based on the integrated program turned to be the best one because of a number of effects of economic, social, environmental, organizational, scientific and applied character. It is expedient to use this approach while orienting state energy policy at the highest possible involvement of alternative energy resources to replace natural gas consumption. This is explained by the fact that the rapid development of alternative power industry can cause not only positive results, but also the negative effects. For calculation these negative effects, forecast their value, development the complex of measures on their minimizing and prevention it is expedient to use integrated approach and system approach that is the base of regional integrated program.

\section{REFERENCES}

[1] Allcott H., Greenstone M. Is there an energy efficiency gap? Journal of Economic Perspectives, American Economic Association 2012:26(1):3-28. doi:10.1257/jep.26.1.3

[2] Ministry of energy and coal industry of Ukraine. Strategy of power industry development [Online]. Available: http://mpe.kmu.gov.ua/minugol/control/uk/doccatalog/list?currDir=50358

[3] Cormio C., Dicorato M., Minoia A., Trovato M. A regional energy planning methodology including renewable energy sources and environmental constraints. Renewable and Sustainable Energy Reviews 2003:7(2):99-130. doi:10.1016/S1364-0321(03)00004-2

[4] Terrados J., Almonacid G., Hontoria L. Regional energy planning through SWOT analysis and strategic planning tools: Impact on renewables development. Renewable and Sustainable Energy Reviews 2007:11(6):1275-1287. doi:10.1016/j.rser.2005.08.003

[5] Terrados J., Almonacid G., Pérez-Higueras P. Proposal for a combined methodology for renewable energy planning. Application to a Spanish region. Renewable and Sustainable Energy Reviews 2009:13(8):2022-2030. doi:10.1016/j.rser.2009.01.025

[6] Asere L., Blumberga A. Government and municipality owned building energy efficiency system dynamics modelling. Energy Procedia 2015:72180-187. doi:10.1016/j.egypro.2015.06.026

[7] Zvingule L., Kalnins S. N., Blumberga D., Gusca J., Bogdanova M., Muizniece I. Improved project management via advancement in evaluation methodology of regional cooperation environmental projects. Scientific Journal of Riga Technical University. Environmental and Climate Technologies 2013:11:57-67. doi:10.2478/rtuect-2013-0008

[8] Telizhenko O. M., Vakulenko I. A., Myroshnychenko Iu. O. Methodological approaches to evaluation the socioecological-economic efficiency of investment projects on energy saving. Energy saving. Power engineering. Energy audit 2014:11:40-51.

[9] Behrens W., Hawranek P. M. Manual for the preparation of industrial feasibility studies. Vienna: Unido Publication, 1991.

[10] Mills E., Kromer S., Weiss G., Mathew P. A. From volatility to value: analysing and managing financial and performance risk in energy savings projects. Energy Policy 2006:34:188-199. doi:10.1016/j.enpol.2004.08.042 
[11] Telizhenko O. M., Zhulavskyy A. Yu., Kyslyy V. M. et. al. Ekonomichnyy potentsial administratyvnykh ta vyrobnychykh system [The economic potential of administrative and production systems]. Sumy: Universitetskaia kniga, 2006.

[12] Financial portal of Ministry of Finance [Online]. Available: http://index.minfin.com.ua/index/fdi/

[13] Association of energy auditors in Ukraine. The cost of the energy audit [Online]. Available: http://aea.org.ua/energy-audit/cost-of-energy-audit/

[14] Association of energy auditors in Ukraine. Method of pricing for district heating companies energy audit [Online]. Available: $\quad$ http://aea.org.ua/2013/06/metodika-tsinoutvorennya-na-energoaudit-pidpriyemstv-tsentral-nogoteplopostachannya/

[15] Department of statistics in the Sumy region [Online]. Available: http://sumy.ukrstat.gov.ua/?menu=105\&level=3/

[16] Cabinet of Ministers of Ukraine. Resolution of the Cabinet of Ministers of Ukraine N 830 "On approval of provisions for planning, accounting and calculation of the cost of research and development work" [Online]. Available: http://zakon2.rada.gov.ua/laws/show/830-96-\%D0\%BF

[17] State agency on energy efficiency and energy saving of Ukraine SAEE. Standard procedure - General requirements for organizing and conducting energy audit No 56 [Online]. Available: http://naer.gov.ua/normativno-pravovi-akti.

[18] Olsthoorna X., Tytecab D., Wehrmeyerc W., Wagnerc M. Environmental indicators for business: a review of the literature and standardisation methods. Journal of Cleaner Production 2001:9(5):453-463. doi:10.1016/S09596526(01)00005-1

[19] Balatskiy O. F. Antologiia ekonomiki chistoy sredy [Anthology economy clean environment]. Sumy: Universitetskaia kniga, 2007.

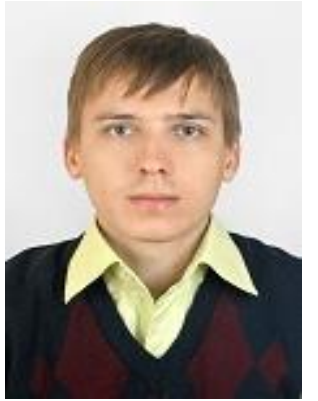

Ihor Vakulenko is a lecturer of Department of Management, Sumy State University, Ukraine. He takes an active part in scientific research for developing energy saving projects in Sumy region. In particular, he participated in the development of Regional program on the heating systems modernization in Sumy region (the collaboration with the Department of City Planning, Architecture and Housing and Communal Services of Regional State Administration in Sumy Region with aim to develop Regional Program on the heating systems modernization), 2013-2014.

Research interests are related to studies of principles and mechanisms for the rational use of energy, alternative energy sources.

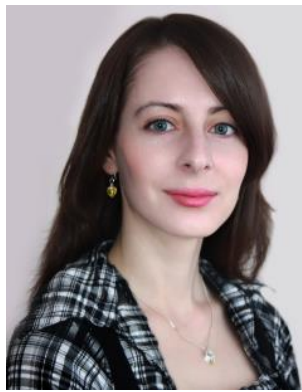

Iuliia Myroshnychenko is a senior lecturer of the Sumy State University, Faculty of Economics and Management, Department of Management, Ukraine. Iu. Myroshnychenko obtained $\mathrm{PhD}$ (Economics) at the Sumy State University in 2011. She participated in the development of Regional program on the heating systems modernization in Sumy region (the collaboration with the Department of City Planning, Architecture and Housing and Communal Services of Regional State Administration in Sumy Region with aim to develop Regional Program on the heating systems modernization), 2013-2014.

Research interests are related to studies of modeling of macro- and microeconomic processes, the analysis of economic processes cyclicity, the evaluation of the effectiveness of the measures for energy saving and the transfer to the alternative fuels. 